\title{
脳神経外科における们確な遺伝子執断のための手法
}

\author{
富
}

\section{Genetic Diagnosis}

by

Toshiyuki Miyata, Ph.D.

from

Department of Etiology and Pathogenesis, National Cardio-vascular Center Research Institute

Recently, attention has been focused on single nucleotide polymorphisms (SNPs). SNPs are useful not only as markers for human genetic studies because of their high density, but also because they make it easy to perform large-scale genotyping using high-throughput methods. Monitoring SNPs may help gene hunters to trace sequences associated with susceptibility to common diseases. A large number of SNPs are deposited in the public database, dbSNP at the L.S. National Center for Biotechnology Information. We validated 525 candidate SNPs by DNA sequencing of samples from Japanese individuals, and a total of 143 SNPs $(27 \%)$ were identified. In Japan, the JSNP project is underway and many SNPs have been identified. In the near future, the genotyping of SNPs will identify the susceptible genes of common diseases.

(Reccived July 29, 2002； accepted September 24, 2002)

Key words : single nucleotide polymorphism, microsatellite DNA, JSNP, SNP

\section{Jpn J Neurosurg（Tokyo）12:156 160, 2003}

\section{はじめに}

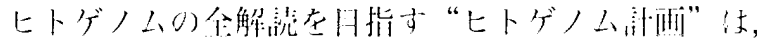

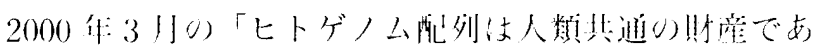

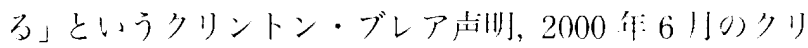
ントン大統垥が主催した目際チームとセレラ・ジ工ノミ

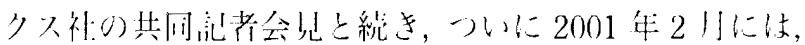

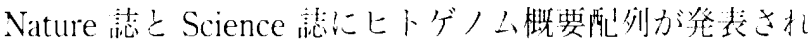

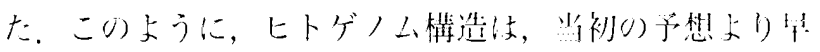
く明らかになった。そして悓倠では，ゲノム研究はポ

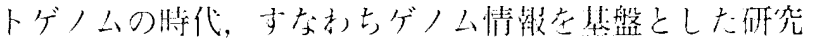
へとシフトしつー好る上うに欢える。

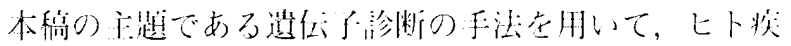

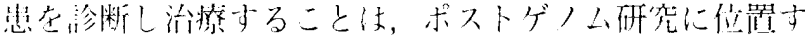

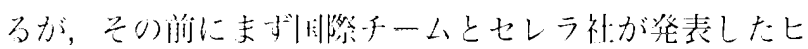

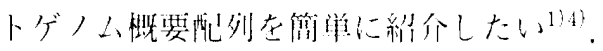

\section{ヒトゲノムの概要配列}

Table 1 法目際チームとセレラ社が発表したヒトゲ，

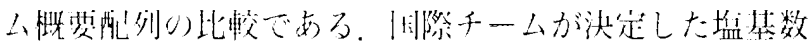

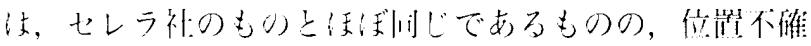

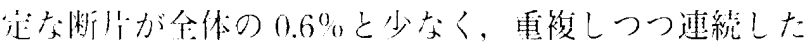
クローン化 DNAの集价体であるコンティグ数もセレラ

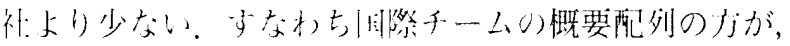
つながりか人きいことを小している。また同際千一ムは，

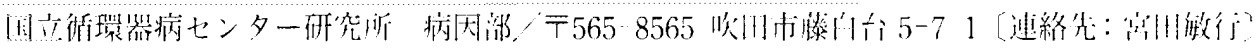

Address reprint requests to: Toshiyuki Miyata, Ph.D., Department of Etiology and Pathegenesis, National Cardio vascular Center Research Institute, 5-7 1 Fujishirodai, Suita shi, Osaka 565-8565, Japan 
Table 1 Human genome draft sequence ${ }^{1 / 4)}$

\begin{tabular}{lcc}
\hline & $\begin{array}{c}\text { International } \\
\text { Consortium }\end{array}$ & $\begin{array}{c}\text { Celera } \\
\text { Genomics }\end{array}$ \\
\hline Number of base pairs & 2.72 billion bp & 2.65 billion bp \\
Covered region & $85 \%$ & $83 \%$ \\
Strategy & hierarchical & whole genome \\
& shotgun sequencing & shotgun sequencing \\
Number of genes & 31,000 & $26,383 \sim 39,114$ \\
SNPs identified & 140 million & 210 million \\
Sequence accuracy & $99.99 \%$ & $99.96 \%$ \\
Number of unpositioned fragments & $0.6 \%$ & $8.7 \%$ \\
Number of contigs & 6,094 & 54,061 \\
\hline
\end{tabular}

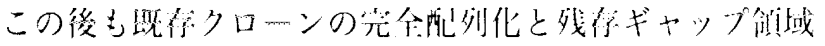

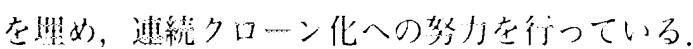

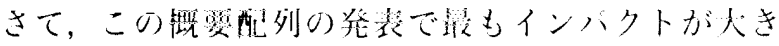

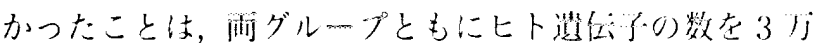

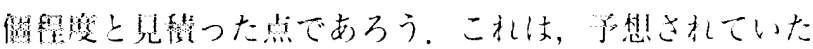
数上りかなり少なく，大きな警き在わって迎えら机た。

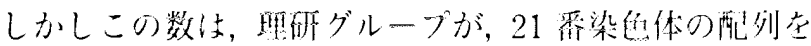

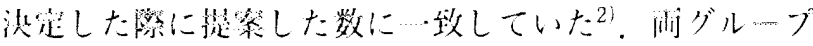

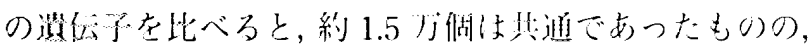

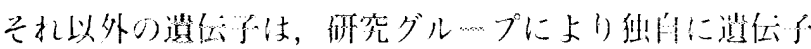
であるもア晦されたものであることが相明した。このこ

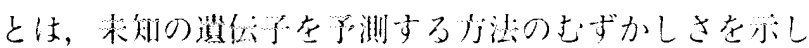
ている

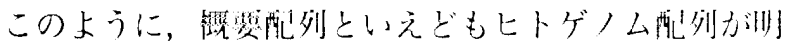

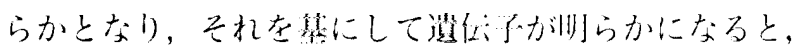

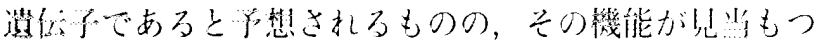
かないものがかなり多くある（七レラ社のデー夕では新 10\%にのぼる)ことが判明した。このこと恔，思在刘

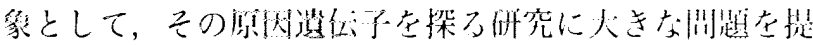

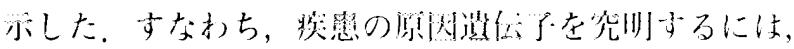

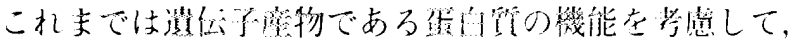

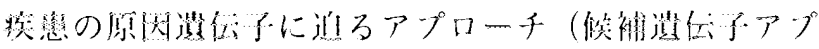
ロータ）が流であった。しかしこのた江では，㙨能未

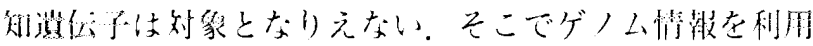

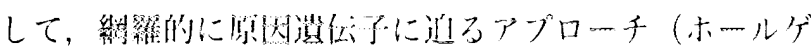

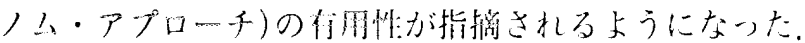

\section{マイクロザテライト多型と 1 潪基多型}

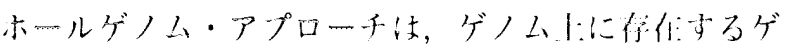

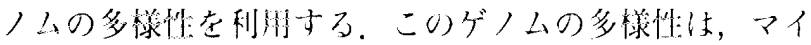

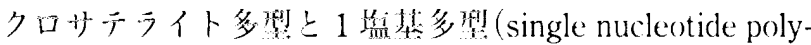

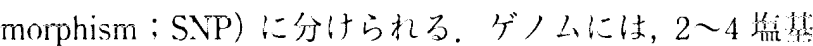

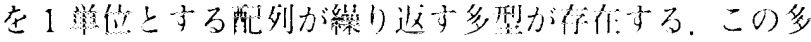

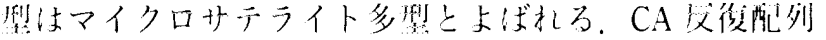
から成るマイクロ+テライト多琶は，七トゲノんにに約

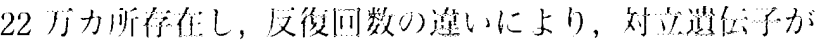
10 所以にに及ぶこともむる。

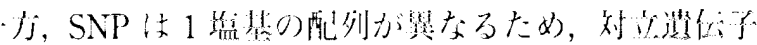
は2つであるが，七ト全ゲノム1:にきおめて多数 (300

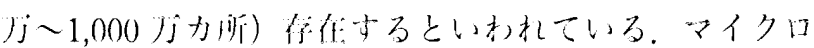

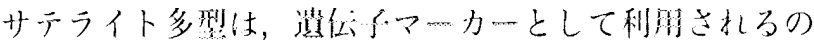

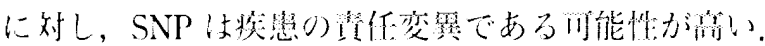

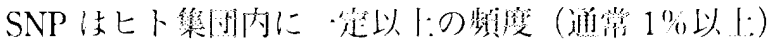

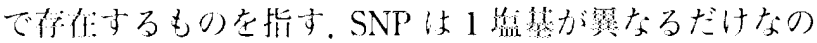

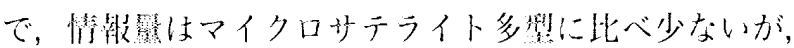

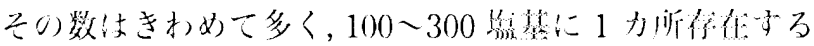
といれ扎る。また，夕イピングの四動化が团能であるの

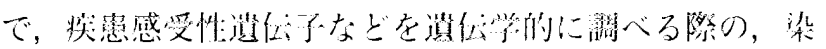

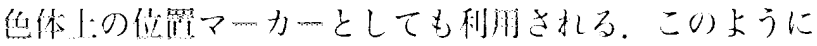

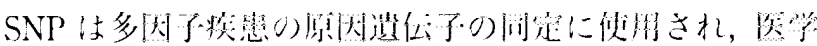

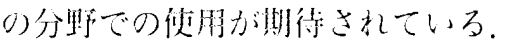

\section{SNP の公開データベース}

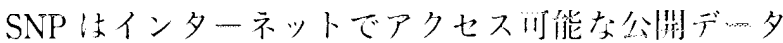

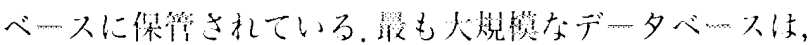

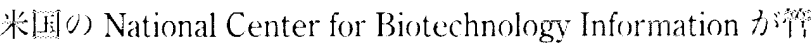

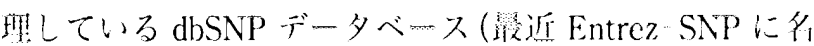

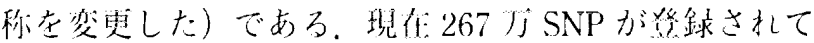

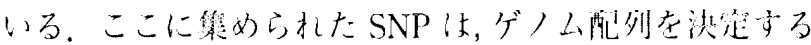

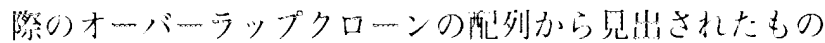

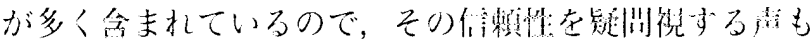

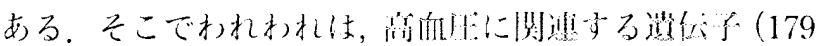

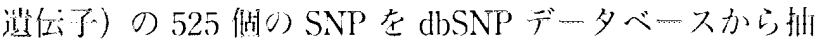

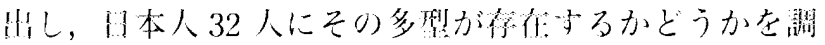

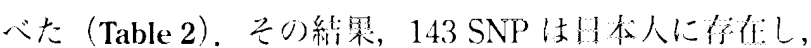

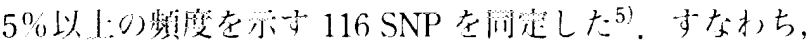


Table 2 Allele frequency of 159 SNPs in 93 hypertension candidate genes in Japanese ${ }^{5}$

\begin{tabular}{cccc}
\hline $\begin{array}{c}\text { Minor allele } \\
\text { frequency }\end{array}$ & $\begin{array}{c}\text { Number of } \\
\text { SNPs }\end{array}$ & $\begin{array}{c}\text { Number of } \\
\text { new SNPs }\end{array}$ & $\begin{array}{c}\text { Number of } \\
\text { total SNPs }\end{array}$ \\
\cline { 1 - 2 } $1 .\left(0-5.0^{\circ} \%\right.$ & $27\left(5^{\circ} \%\right)$ & 13 & 40 \\
$5.1-25.0^{\circ} \%$ & $53\left(10^{\circ} \%\right)$ & 3 & 56 \\
$25.1-50.0^{\circ} \%$ & $\left.63(1)^{\circ} \%\right)$ & 0 & 63 \\
Total & $143(27 \%)$ & 16 & 159 \\
\hline
\end{tabular}

SNP : single nucleotide polymorphism

( ) : ${ }_{0}$ of the total SNPs $(n=525)$

dbSNPデータバースに恪納さ扎ているSNPのうち,

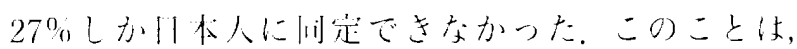

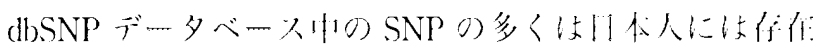

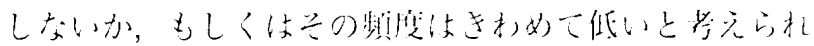
た。

川本で行才机ている Japanese SNP（JSNP）は，选伝 アのエタリンとプロモーター们域にしばってシークエン

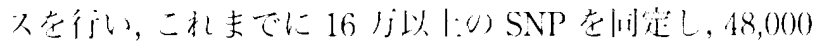
以上のSAPの频度情能を公间している（http：

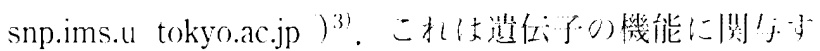

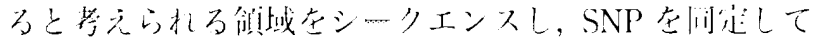

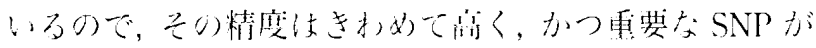

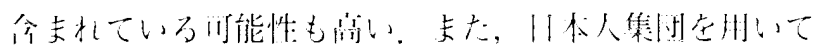

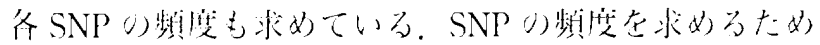

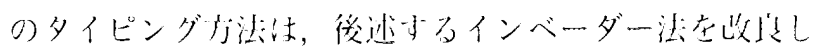
て触いている。关扎，マルチブレックス polymerase

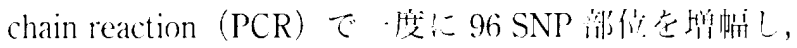

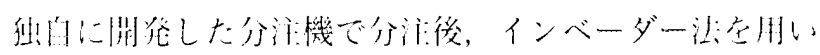

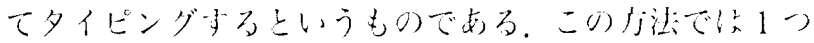

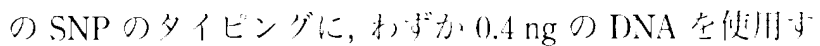

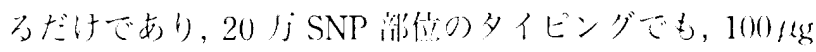

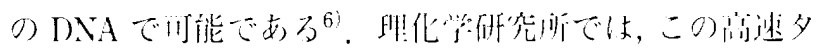

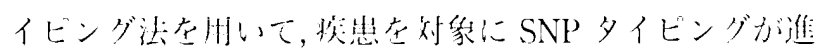

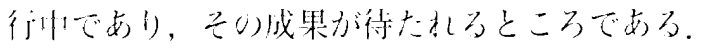

\section{ハプロタイプブロック}

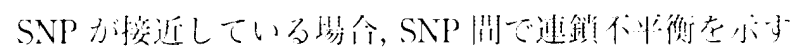

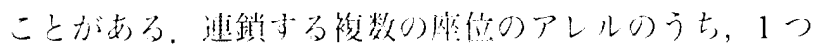

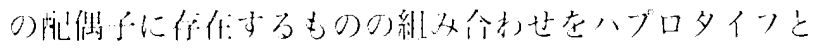

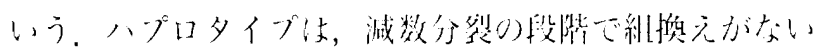

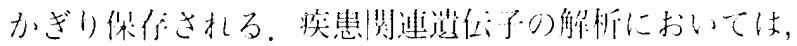

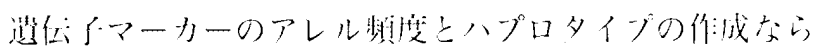
びに頻度が币曹で女る。食ゲ/ムにおたのて夕イビング
Table 3 SNP blocks in chromosome $21^{71}$

\begin{tabular}{cccc}
\hline $\begin{array}{c}\text { Common } \\
\text { SNPs } \\
\text { block }\end{array}$ & $\begin{array}{c}\text { No. of } \\
\text { blocks }\end{array}$ & $\begin{array}{c}\text { Avg. size } \\
\text { block (kb) }\end{array}$ & $\begin{array}{c}\text { Avgo } \\
\text { common } \\
\text { haplotypes' } \\
\text { block }\end{array}$ \\
310 & 589 & 23.90 & 3.75 \\
31010 & 1,408 & 8.52 & 2.92 \\
3 & 2,138 & 2.96 & 2.30 \\
Total & 41.35 & 7.83 & 2.72 \\
\hline
\end{tabular}

A total of 24,047 SNPs are classified into the SNP blocks.

No. : number Avg. : average

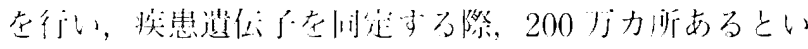

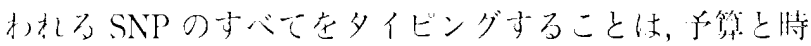

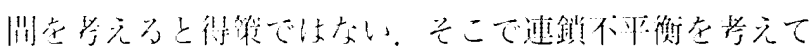

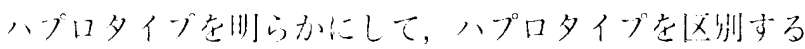

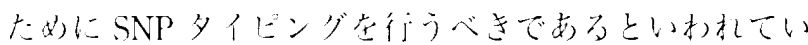
2.

このハグロ多イブが保保さ扎ている邻域は，数 $\mathrm{kb}$

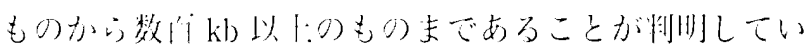

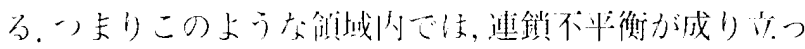

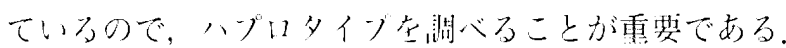
籍 21 番染出体个域の24,047 S.NP在20染出体で夕イピ

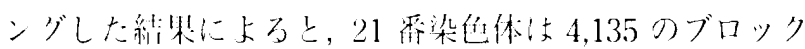

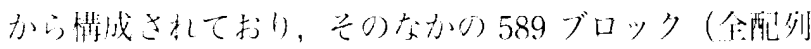

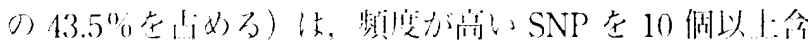

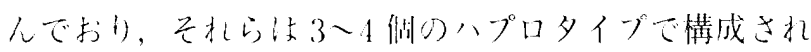
ているフ' (Table 3).

\section{大規模 SNP タイピング法}

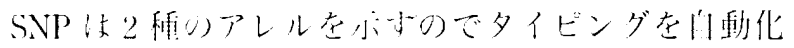

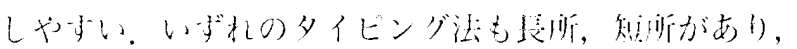

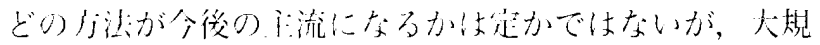

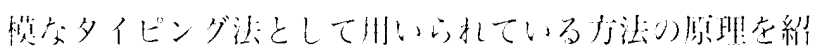
介南\%。

\section{1) タックマン PCR 法}

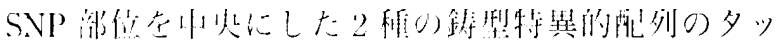
クマンブローブが，多型在涐别子る。このプローブの 5

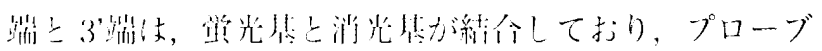

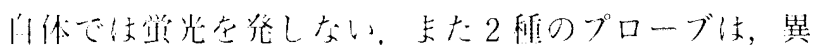

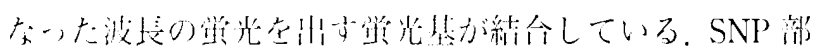

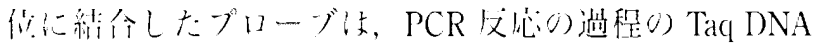

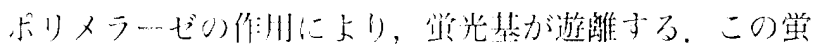
㪇に上り多型のタイピング在行う。このように本法は 2 


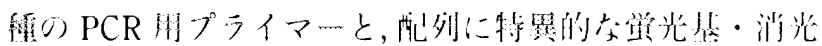
はが練命した 2 盉のタックマンプローブが必要である。

\section{2 インベーダー法}

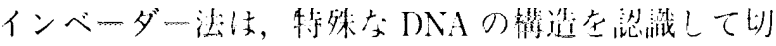
銜なるエンドヌクレアーゼ (cleavase) を利州したもの

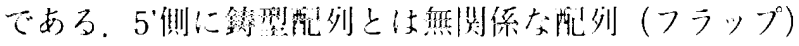

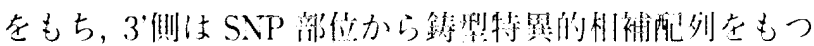
アリルブローブと，SNP㑲借から3侧に相補的であり

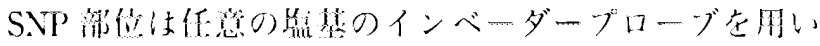

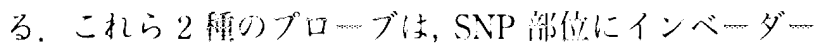

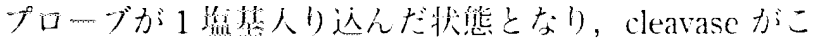

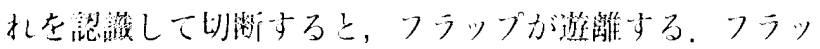

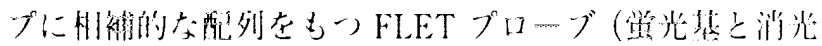

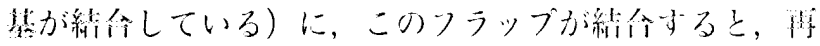

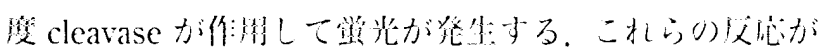

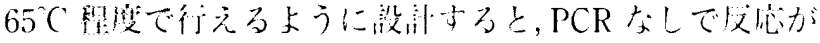
繰り这しけおれ，タイピングが川能上なる。

\section{3 漓㴧虔オリゴヌクレオチドデップ}

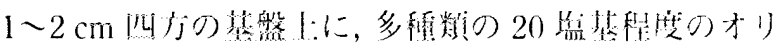
ゴヌクレオチド在，富密㦄に整列化し间定したDNA

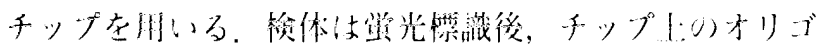
ヌクレオチドとアレル特罢的なハイブリダイゼ一ション

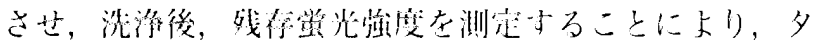
イピングを行う。この坊沚は，侗人ごとに1坆のチップ

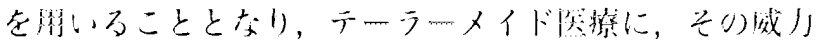

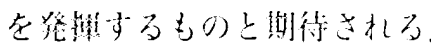

\section{おわりに}

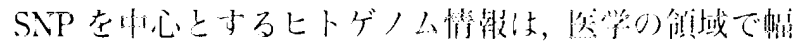

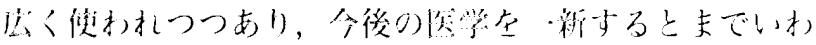

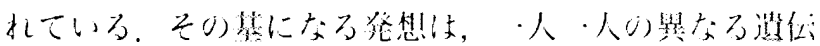

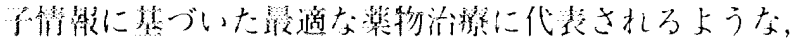

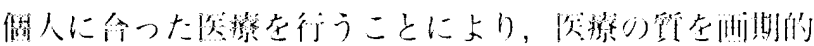

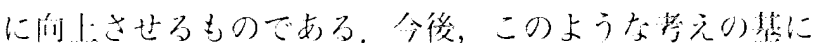

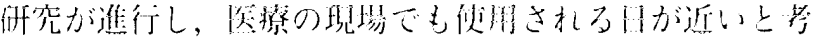
え万。

\section{文 献}

1) Celera Genomics: The sequence of the human genome. Science 291: 1304 1351, 2001.

2) Hattori M, Fujiyama A, Taylor TD, Watanabe $H$, Yada $T$, Park HS, Toyoda A, Ishii K, Totoki Y, Choi I)K, Groner Y, Soeda E, Ohki M, Takagi T, Sakaki Y, Taudien S, Blechschmidt K, Polley A, Menzel L, Delabar J, Kumpf K, Lehmann R, Patterson D, Reichwald K, Rumip A, Schillhabel M, Schudy A, Zimmermann W, Rosenthal A, Kudoh J, Schibuya K, Kawasaki K, Asakawa S, Shintani A, Sasaki T, Nagamine K, Mitsuyama S, Antonarakis SE, Minoshima S, Shimizu N, Nordsiek G, Hornischer K, Brant P, Scharfe M, Schon O, Desario A, Reichelt J. Kauer (r, Blocker II, Ramser J, Beck A, Klages S, Hennig S, Riesselmann L, Dagand E, Haaf T, Wehrmeyer S, Berzym K, Gardiner K, Nizetic D), Francis F, Lethrach H, Reinhardt R, Yaspo ML : The DNA sequence of human chromosome 21. Nature $\mathbf{1 0 5}$ : $311-319,2000$.

3) Hirakawa M, Tanaka T, Hashimoto Y, Kurodla M, Takagi T, Nakamura Y: JSNP : A database of common gene variations in the Japanese population. Nucleic Acids Res 30: $158162,2002$.

4) International Human Genome Sequencing Consortium: Initial sequencing and analysis of the human genome. Nature 109: 860 $921,2001$.

5) Okuda T, Fujioka $Y$, Kamide $K$, Kawano $Y$, Goto $Y$, Yoshimasa $Y$, Tomoike II, Iwai $\mathrm{N}$. Hanai S, Miyata T: Verification of 525 coding SNPs in 179 hypertension candidate genes in the Japanese population: Identification of 159 SNPs in 93 genes. J Hum Genet 8:387-394, 2002.

6) Ohnishi Y, Tanaka T, Ozaki K, Yamada R, Suzuki II, Nakamura $Y: A$ high throughput SNP typing system for genome wide association studies. J Hom Genet 16:471 477, 2001.

7) Patil N, Berno AJ. Ifinds DA, Barrett WA, Doshi JM, Hacker CR, Kautzer CR, Lee DH, Marjoribanks C, McDonough DP, Nguyen BT, Norris MC, Shechan JB, Shen N, Stern I), Stokowski RP, Thomas DJ, Trulson .MO, Vyas KR, Frazer KA, Fodor SP, Cox DR: Blocks of limited haplotype diversity revealed by high resolution scanning of human chromosome 21. Science 294: 1719 1723, 2001. 
脳神経外科における的確な遺伝子診断のための手法

宮田 敏行

ヒトゲノム上の遺伝子多型，特に 1 塩基多型 (single nucleotide polymorphism：SNP) が医学の分 野で注目を策めている.SNPは数がきわめて多いので，疾患の珼任变異である可能性が高い.SNP は公開データベースに格納されている，日本人 DNA を用いて公開データベーース内の 525 個の SNPS を調べたところ，27\%にあたる 143 個しか確認されなかった. 日本では遺伝子領域を再シークエンス し、SNPを同定するプロジェクトが行われ，多数のSNPs が見出されている. 今後、SNPをタイピ ングすることにより，種々の疾患に関わる遺伝子が同定されるものと考えられる。

脳外誌 $12: 156-160,2003$ 